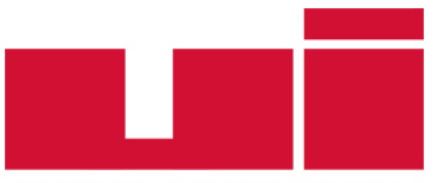

ULUUSLARARASTILIŞKiLER

Akademik Dergi

Yayın ilkeleri, izinler ve abonelik hakkında ayrıntılı bilgi:

E-mail: bilgi@uidergisi.com.tr

Web: www.uidergisi.com.tr

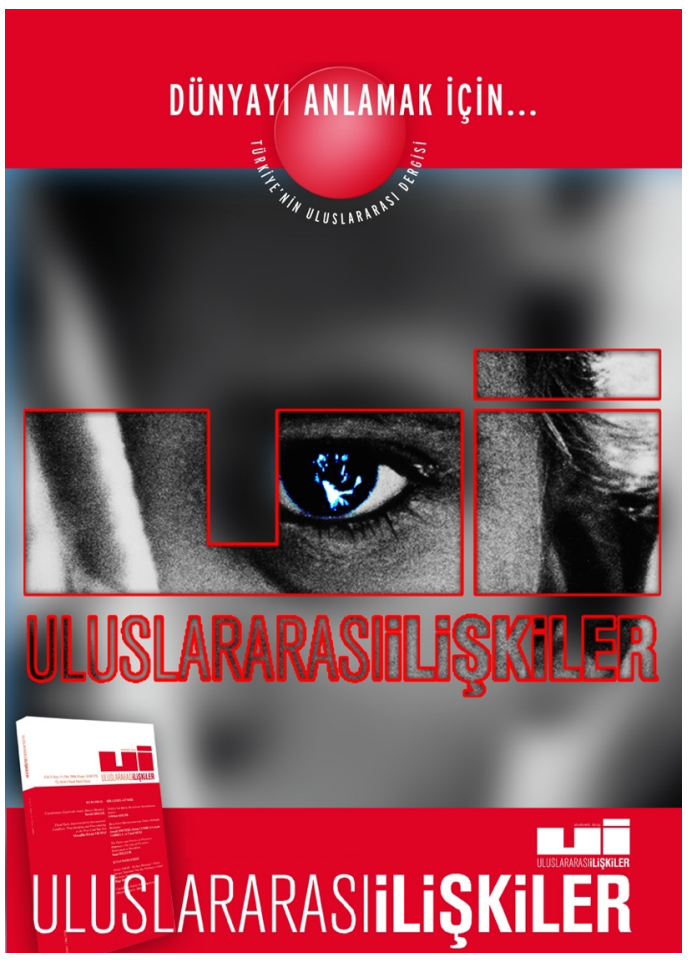

\title{
Avrupa Birliği Genişlemesinde Azınlık Koşulu: Doğu Genişlemesi ve Türkiye
}

\author{
Hatice YAZGAN* \\ * Yrd. Doç. Dr., Çankırı Karatekin Üniversitesi, Uluslararası \\ İlișkiler Bölümü
}

Bu makaleye atıf için: Yazgan, Hatice, “Avrupa Birliği Genişlemesinde Azınlık Koşulu: Doğu Genişlemesi ve Türkiye”, Uluslararası İlişkiler, Cilt 12, Sayı 47, s. 99-114.

Bu makalenin tüm hakları Uluslararası İlişkiler Konseyi Derneği'ne aittir. Önceden yazılı izin alınmadan hiç bir iletişim, kopyalama ya da yayın sistemi kullanılarak yeniden yayımlanamaz, çoğaltılamaz, dağıtılamaz, satılamaz veya herhangi bir şekilde kamunun ücretli/ücretsiz kullanımına sunulamaz. Akademik ve haber amaçlı kısa alıntılar bu kuralın dışındadır.

Aksi belirtilmediği sürece Uluslararası Illişkiler'de yayınlanan yazılarda belirtilen fikirler yalnızca yazarına/yazarlarına aittir. UİK Derneğini, editörleri ve diğer yazarları bağlamaz.

Uluslararası İlişkiler Konseyi Derneği | Uluslararası İlişkiler Dergisi

Web: www.uidergisi.com.tr| E- Posta: bilgi@uidergisi.com.tr 


\title{
Avrupa Birliği Genişlemesinde Azınlık Koşulu: Doğu Genişlemesi ve Türkiye
}

\author{
Hatice YAZGAN \\ Yrd. Doç. Dr., Uluslararası İlişkiler Bölümü, İIBF, Çankırı Karatekin Üniversitesi, Çankırı. \\ E-posta: hyazgan@karatekin.edu.tr. Çalışmanın literatür araştırması, Temmuz/Ağustos 2014 tarihinde yazarın ziyaretçi \\ araştırmacı olarak bulunduğu European Centre for Minority Issues, Flensburg/Almanya'da gerçekleştirilmiştir.
}

\begin{abstract}
ÖZET
Azınlıkların korunması, Avrupa Birliği’nin (AB) genişleme kapsamına aldığı ülkelere uyguladığı koşullardan biridir. Makalenin amacı, AB'nin genişleme politikası kapsamında uyguladığı azınlık politikalarının Türkiye için sonuçlarını inceleyerek, Doğu genişlemesi sırasında Macaristan, Estonya ve Letonya'daki azınlıklar ile Türkiye'de Kürt meselesine $\mathrm{AB}$ etkisinin karşılaştırmalı analizini yapmaktır. Makalede; $\mathrm{AB}$ tarafından azınlık politikaları bağlamında değerlendirilen Kürt meselesinin, azınlıklara ilişkin güvenlik vurgusu dikkate alınarak, mevcut durumuyla AB'nin güvenlik ve istikrarına ilişkin endişelere neden olduğu öne sürülmektedir. Birlik bu endişeyi gidermekte yetersiz kalmıştır ve diğer ülkelerle karşılaştırıldığında, Türkiye örneğinde $\mathrm{AB}$ etkisi sınırlıdır. Türkiye- $\mathrm{AB}$ ilişkilerindeki ve $A B$ azınlık politikasındaki sorunlar, Türkiye'nin bu konudaki siyasi tercihlerini ve geleneksel politikasını sürdürmesini kolaylaştırmaktadır.
\end{abstract}

Anahtar Kelimeler: AB’de Azınlıklar, Doğu Genişlemesi, Güvenlik, Koşulluluk, Kürt Meselesi.

\section{The Minority Condition in EU Enlargement: The Eastern Enlargement and Turkey}

\begin{abstract}
Protection of minorities is one of the conditions that the EU applies to candidate countries. This article evaluates the consequences of EU minority policies for Turkey by comparing the EU's impact on minorities in Hungary, Estonia and Latvia during the Eastern enlargement to the Kurdish issue in Turkey. Bearing in mind the EU's security considerations regarding minorities, the article argues that the Kurdish issue, which the EU treats as a minority issue, currently remains one of its security concerns. The EU has been unable to alleviate its concerns and its impact has remained limited compared to the other cases. Problems between Turkey and the EU and deficiencies in EU minority policy have helped sustain Turkey's traditional policies and domestic preferences regarding the Kurdish issue.
\end{abstract}

Keywords: Minorities in the EU, Eastern Enlargement, Security, Conditionality, Kurdish Issue. 


\section{Giriş}

1993 yılında oluşturulan Kopenhag siyasi kriterleri arasında azınlıkların korunmasını sayan AB'nin bu alanda bir aktör olarak ortaya çıkması, uluslararası hukukta tartışmalı olan azınlık konularına yeni bir boyut kazandırmıştır. Doğu genişlemesi ülkelerine uygulanmaya başlanan $\mathrm{AB}$ azınlık kriteri, kimi ülkelerin karışık etnik yapıları nedeniyle önplana çıkmış ve azınlık konularının siyasi tartışmaları tetikleme potansiyeli taşıması, farklı faktörlerle birlikte $A B$ etkisini bu ülkelerde uzun süre tartışmalı hale getirmiştir. Azınlık koşulunun siyasi karakteri Türkiye için de araştırılması gereken sonuçlara yol açabilir. Makalenin amacı, AB’nin genişleme politikası kapsamında uyguladığı azınlık politikalarının Türkiye için sonuçlarını inceleyerek, Doğu genişlemesi sırasında Macaristan, Estonya ve Letonya'daki azınlıklar ile Türkiye’de Kürt meselesine $\mathrm{AB}$ etkisinin karşılaştırmalı analizini yapmaktır.

Makalede, 2004 yılında $\mathrm{AB}$ üyesi olmuş ülkelerden, katılım sürecinde koşul gereklerini göreli olarak daha iyi uygulayan Macaristan ile gerek $\mathrm{AB}$ etkisinin görülmesi, gerekse uygulama konusunda sorunlar yaşayan Estonya ve Letonya örnekleri incelenmiş̧ir. Macaristan örneğinde Macar azınlığın bulunduğu bazı ülkelerdeki $\mathrm{AB}$ etkisi, tipik özellikleri nedeniyle inceleme kapsamına alınmıştır. Makalede Türkiye'nin azınlık tanım ve politikaları içinde yer almayan ancak $A B$ tarafından azınlık politikaları bağlamında değerlendirilen Kürt meselesinin incelenmesi, $\mathrm{AB}$ politikalarındaki güvenlik vurgusu nedeniyledir. Doğu genişlemesinde AB'nin diş politika ve güvenlik endişeleri nedeniyle bazı azınlıkların ön plana çıkarıldığı ifadesinden hareketle, makalede Türkiye'de Lozan Antlaşması ile azınlık olarak kabul edilen gruplardan farklı olarak mevcut durumuyla çatışma unsurları barındıran Kürt meselesi $\mathrm{AB}$ bakış açısından incelenmiştir. Makale $\mathrm{AB}$ etkisine odaklandığından, Kürt meselesinin ve incelenen azınlık sorunlarının tarihsel ve toplumsal bağlamı inceleme kapsamı dışında tutulmuştur. Literatürde; AB'nin (azınlık koşulunun) gerek geçmiş ve mevcut aday ülkelere, gerekse Kürt meselesine etkilerini inceleyen çok sayıda araştırma mevcuttur. Ancak Türkiye örneği ile farklı ülkelerin tecrübelerinin ve genişleme kapsamında $\mathrm{AB}$ azınlık politikasının Türkiye açısından sonuçlarının analiz edildiği çalışmalara gereksinim sürmektedir.

Makalede ilk olarak azınlıklara ilişkin $A B$ politikalarının ortaya çıkış sebepleri ve içeriği incelenecektir. Ardından AB'nin Doğu genişlemesi ülkelerine yaklaşımı örneklerle ortaya konacak ve Türkiye'nin durumu analiz edilecektir.

\section{AB Azınlık Politikası, İlgili Mevzuat ve Sorunlar}

$\mathrm{AB}$ bütünleşmesi başta ekonomik bakımdan benzersiz bir seviyeye gelmesine rağmen, Doğu genişlemesi sürecinin başlangıcına dek azınlıklar konusunda ortak mevzuat ve temel bir politika oluşturulmamıştır. AB 1990'lara dek azınlıklar ve ilgili konuları üye devletlerin yetkisine bırakmıştır. Bir görüşe göre, $A B$ 'nin azınlıklar konusundaki uzun süren hareketsizliği, üye devletlerin bu konuda AB kurumlarına yetki devretme konusunda uzlaşmaya varamamasından kaynaklanmaktadır. ${ }^{1}$

1990’lı yılların başından itibaren, Doğu Genişlemesi sürecinde AB, azınlık konuları da dâhil olmak üzere siyasi konulara dair düzenlemeler yapmaya başlamıştır. Öncelikle, etnik kıyım ve şiddet gibi olumsuz tecrübelere sahip azınlıklara karşı duyulan insani endişenin bu düzenlemelerde etkili olduğunu vurgulayan görüşler vardır. Bunun yanında, Batıda, post-komünist devletlerin kendi

1 Gabriel N. Toggenburg, "Minority Protection in a Supranational Context: Limits and Opportunities", Gabriel N. Toggenburg (der.), Minority Protection and the Enlarged European Union: The Way Forward, Local Government and Public Service Reform Initiative Open society Institute, Budapeşte, Macaristan, 2004, s.10-13. 
etnik çeşitliliklerini yönetebilmelerinin, siyasi olgunluklarını ve Avrupa'ya yeniden katılmaya hazır olduklarını gösteren bir test olacağına dair inanç azınlıklara ilişkin düzenlemelerin temel nedeni olarak görülmüştür. ${ }^{2}$ Ancak, azınlıklara ilişkin düzenlemelerin 1990'lar sonrasında yoğunlaşmasının sebepleri arasında bu ülkelerin azınlık sorunlarının yaratacağı güvenlik ve istikrar sorunlarının ön plana çıktığı görülmektedir. Bu görüşe göre, post-komünist demokrasiler azınlık hakları bakımından istikrarlı düzenlemeler yapamadıkları takdirde etnik ve sosyal sorunlarını Batı'ya ihraç edebilir ve Avrupa'nın güvenlik ve istikrarını etkileyebilirler. ${ }^{3}$ Bu bakışın temelinde Kosova ve Bosna Hersek örneklerinde de görüldüğg̈ üzere, artan etnik şiddetin Batı Avrupa'ya geniş çaplı mülteci akınına sebep olabileceği ve etnik savaşların, kanunsuz işler için elverişli bir ortam yaratabileceği endişeleri yatmaktadır. ${ }^{4}$

Hughes ve Sasse'ye göre, AB ilerleme raporlarında Doğu Genişlemesi ülkelerinin hemen hepsinin azınlık nüfusuna sahip olmalarına rağmen çoğunlukla iki grup (Estonya ve Letonya'da Rus (Rusça konuşan) azınlık ve Bulgaristan, Çek Cumhuriyeti, Macaristan, Romanya ve Slovakya'da Romanlar) üzerinde durulmaktadır. Bu hiyerarşi, AB’nin güçlü komşusu ve enerji tedarikçisi Rusya ile ilişkilerini düzenleme çabasını ve Romanların göç hareketlerine yönelik yumuşak güvenlik endişelerini yansıtmaktadır. ${ }^{5}$

Azınlık haklarının genellikle demokrasi ve insan hakları bağlamında tartışılmasına karşılık, azınlık koşulunun $A B$ 'nin güvenlik endişelerinin sonucu olduğu yönündeki görüşlere rağmen, $A B$ ’nin etnik ilişkileri yönetme konusundaki etkisi yadsınmamaktadır. ${ }^{6}$ Azınlık düzenlemelerinin temelindeki güvenlik endişeleri, AB örneğinde, Sasse tarafından "güvenlik-haklar bağı" (security-rights nexus) olarak kavramsallaştırılan şekliyle, azınlıklara hakları verilerek giderilmeye çalışılmaktadır. ${ }^{7}$ Bir başka deyişle, $\mathrm{AB}$ azınlık politikalarının temelinde güvenlik endişeleri yatsa da; politikalar, azınlıkların hakları temel alınarak düzenlenmektedir.

Avrupa düzeyinde azınlıklara ilişkin düzenlemeler, AB’nin yanında Avrupa Konseyi ve Avrupa Güvenlik ve İşbirliği Teşkilatı (AGİT) tarafından gerçekleştirilmektedir. Bu kuruluşların azınlıklara ilişkin düzenlemeleri "Avrupa Azınlık Hakları Rejimi” olarak adlandırılmaktadır. ${ }^{8}$ Birleşmiş Milletler (BM)'in de dâhil edilebileceği bu rejim çerçevesinde AB'nin düzenlemeleri, aslında Birinci Dünya Savaşı sonrası Milletler Cemiyeti ile başlayan, İkinci Dünya Savaşı sonrası insan hakları çerçevesinde ele alınan, Soğuk Savaşın bitimi ile kısmen tekrar azınlıkların korunması şekline dönüşen politikaların bir parçasıdır.

2 Will Kymlicka, “The Evolving Basis of European Norms of Minority Rights: Rights to Culture, Participation and Autonomy", Marc Weller et.al. (der.), The Protection of Minorities in the Wider Europe, Palgrave Macmillan, 2008, s.13-14.

3 Wojciech Sadurski, "Minority Protection in Central Europe and Accession to the EU”, Weller et.al. (der.), The Protection of Minorities in the Wider Europe, s.209. Konuyu güvenlik bağlamında inceleyen bir başka görüş için bkz. Toggenburg, "Minority Protection in a Supranational Context", s.7.

4 Kymlicka, “The Evolving Basis”, s.13-14.

5 James Hughes ve Gwendolyn Sasse, "Monitoring the Monitors: EU Enlargement Conditionality and Minority Protection in the CEECs", Journal on Ethnopolitics and Minority Issues in Europe, Cilt 1, 2003, s.16; Gwendolyn Sasse, "Minority Rights and EU Enlargement: Normative Overstretch or effective conditionality?" Toggenburg (der.), Minority Protection and the Enlarged European Union, s.66-67.

6 David Galbreath ve Joanne Mcevoy, "European organizations and minority rights in Europe: On transforming the securitization dynamic", Security Dialogue, Cilt 43, No.3, 2012, s.267-284.

7 Gwendolyn Sasse, "Securitization or Securing Rights? Exploring Conceptual Foundations of Policies towards Minorities and Migrants in Europe”, JCMS, Cilt 43, No.4, 2005, s.673-693.

8 David Galbreath ve Joanne Mcevoy, The European Minority Rights Regime, Towards a Theory of Regime Effectiveness", ABD, Palgrave Macmillan, 2012, s.2-3. 


\section{Genişleme ve Azınlık Mevzuatı}

Kymlicka'ya göre Avrupalı kuruluşların post-komünist devletlerin azınlıkları için oluşturduğu düzenlemeler, mevcut uluslararası düzenlemelerin öngörmediği yeni bir yaklaşım ihtiyacından doğmuştur.9 Böylelikle, Avrupa Konseyi tarafından "Ulusal Azınlıkların Korunması Çerçeve Sözleşmesi" (Framework Convention for the Protection of National Minorities- FCNM) ve "Avrupa Bölgesel veya Azınlık Dilleri Şartı" (European Charter for Regional or Minority Languages-ECRML) adı ile iki Sözleşme hazırlanmış, ${ }^{10}$ AGİT bünyesinde "Ulusal Azınlıklar Yüksek Komiserliği" oluşturulmuştur. $\mathrm{AB}$ içinde azınlık konuları genişleme politikası ile daha fazla gündeme gelmeye başlamıştır. AB'ye katılacak ülkelerin yerine getirmesi gereken Kopenhag Kriterleri içinde "azınlıkların korunması ve (azınlıklara) saygı gösterilmesi ” şeklinde belirtilen koşulun içeriği aday ülkeler için Avrupa Komisyonu tarafindan hazırlanan ilerleme raporları ile şekillenmiştir.

Topidi’ye göre, $\mathrm{AB}$ azınlık hakları politikasının analizi üç çeşit hak açısından yapılmalıdır. Bunlar: Temel haklar, çeşitlilik yanlısı politikalar (pro-diversity) ve vatandaşlık hakları ile ilgili düzenlemelerdir. AB genellikle temel haklar yaklaşımını vurgulasa da, azınlık korumasında farklı ülkelerde farklı yaklaşımlar ön plana çıkabilmektedir. Örneğin Slovakya'da, Roman azınlık ile ilgili sorunların ağırlı̆̆ı nedeniyle çeşitlilik yanlısı yaklaşım, Letonya'da ise, azınlıklara vatandaşlık haklarının verilmesiyle ilgili yaklaşım ön plandadır. Bu da AB'nin azınlık politikasının tek bir yaklaşımla açıklanamayacağını ortaya koymaktadır. ${ }^{11}$

$\mathrm{AB}$ tarafindan Doğu genişlemesi ülkelerinden düzenleme yapılması talep edilen konular ilerleme raporlarında belirtildiği şekliyle temelde şu noktalar üzerinde yoğunlaşmaktadır: ${ }^{12}$ Azınlıkların dilsel ve kültürel kimliklerinin eğitim sistemi yoluyla sürdürülmesi, azınlık dilinde eğitimin sağlanması, azınlık dillerinin kamusal alanda kullanılması, nüfusun yüzde 20'sini geçen azınlıkların kamu idaresi ile kendi dillerinde resmi yazışma yapabilmeleri, azınlıkların siyasi temsili ve günlük yaşamda ayrımcılığa uğramamaları için gerekli zeminin oluşturulması. Ayrıca vatandaşlık konularında, azınlıkların vatandaşlığa geçişinin ve dil sınavlarının kolaylaştırılması, vatandaşlığa başvuru ücretlerinin makul seviyelerde olması, belirli yaş gruplarının vatandaşlık prosedüründen muaf tutulması gibi hususlar üzerinde durulmaktadır.

İlerleme raporlarına yöneltilen eleştiriler arasında, azınlıklarla ilgili koşullar belirli bir $\mathrm{AB}$ mevzuatına denk gelmediğinden, net ölçütlerin (benchmark) olmaması, uygulama konusuna önem verilmemesi, raporlarda belirsiz ve yuvarlak ifadelerin kullanılması sayılabilir. ${ }^{13}$ Ayrıca, ilerleme raporlarında belirtilmeyen bazı azınlık sorunlarının olması, Avrupa azınlık hakları rejiminin az dikkat çeken, küçük azınlıkların sorunları ile ilgilenmede yetersiz kaldığı yönünde eleştirilere sebep olmaktadır. ${ }^{14}$

9 Kymlicka, “The Evolving Basis”, s.16-17.

10 FCNM, ulusal azınlık tanımı yapmaması, azınlıklar için kolektif haklar oluşturmaması, imzacı devletlere uygulamada çok geniş bir alan bırakması ve zayıf kontrol sistemi bakımından eleştirilmektedir. ECRML ise alakart bir sistem oluşturması ve zayıf kontrol sistemine sahip olması bakımından eleştirilmektedir. Christoph Pan ve Beate Sibylle Pfeil, National Minorities in Europe: Handbook, Viyana, Braumüller, 2003, s.202-203. Bu Sözleşmeler yanında, Avrupa İnsan Hakları Mahkemesi (AİHM) ve Avrupa Birliği Adalet Divanı (ABAD) azınlık hakları içtihadı bakımından birbirlerini besleyen pozisyondadır. ABAD dil hakları, AİHM içtihadı ise kültürel haklar konusunda gelişmektedir. Anneleen van Bossuyt, "Fit for Purpose or Faulty Design? Analysis of the Jurispuridence of the European Court of Human Rights and the European Court of Justice on the Legal Protection of Minorities", JEMIE, Say1 1, 2007, s.1-20.

11 Kyriaki Topidi, EU Law, Minorities and Enlargement, Antwerp-Oxford-Portland, Intersentia, 2010, s.219-220.

12 Doğu Genişlemesi ülkeleri ilerleme raporları için bkz. http://ec.europa.eu/enlargement/countries/package/index _ en.htm.

13 Hughes ve Sasse, "Monitoring the Monitors", s.15.

14 Galbreath ve Mcevoy, The European Minority Rights Regime, s.175. 
Avrupa Konseyi Sözleşmelerinin aday ülkelerce kabul edilip edilmediği ilerleme raporlarında üzerinde durulan konulardan biridir. Sözleşmelerin kabulü aday ülkelerin temkinli yaklaşımları nedeniyle kolay olmamaktadır. ${ }^{15}$ Bunun yanında, AB'nin bazı diğer mevzuatının da zaman içinde azınlık politikaları kapsamında aday ülkeler tarafından benimsenmesi gereği ortaya çıkmaktadır. Ancak, $A B$ hukukunda azınlıklara ilişkin temel mevzuat bulunmamaktadır ve ilerleme raporlarında azınlıklara ilişkin olarak uyum sağlanması gerektiği belirtilen mevzuat ve politikalar oldukça dağınıktır. Esas itibariyle $A B$ mevzuatında ayrımcılık karşıtı mevzuat (Irk ve İstihdam Direktifleri ve diğer mevzuat) ve çeşitliliğe (diversity) ilişkin maddeler dolaylı olarak azınlıklara ilişkin mevzuat olarak kabul edilmektedir. ${ }^{16}$

Ayrıca AB üyelik süreci, aday ülkelerde adem-i merkeziyetçiliğin (territorial decentralization) yaygınlaştırılması yönünde reformlara neden olmuştur. $A B$ bölgesel fonlarının doğrudan yerel yönetimlere verilmesi aday ülkelerde yerel yönetimlerin yeniden yapılandırılmasını hızlandırmıştır. Yerel yönetim reformu AB'de ulusal azınlık bölgeleri dikkate alındığında önem kazanmaktadır. Özellikle Doğu genişlemesi ile AB içinde güçlü ulusal azınlık kimliği taşıyan bölge sayısı artmıştır ve bu durum $\mathrm{AB}$ içinde bölgelerin önem kazanmaya başlama eğilimi ile paraleldir. ${ }^{17}$

Öte yandan, AB’nin yukarıda sözü geçen düzenlemelerinin soft-law niteliği taşıdığı belirtilmelidir, zira bu düzenlemeler esnektir ve yaptırım neredeyse yoktur. ${ }^{18} \mathrm{AB}$ hukukunun parçası olduğundan Adalet Divanı yetkisinde kalacak bazı Direktifler dışında, aday ülkelerin $\mathrm{AB}$ üyesi olduktan sonra bu düzenlemelere uyup uymadıklarının denetlenmesi için bir mekanizma olmaması, düzenlemelerin sürdürülebilirliğine ilişkin endişeler doğurmuştur. Bu doğrultuda, azınlık politika ve mevzuatının uygulama sorunları gündeme gelmiştir. ${ }^{19}$ Bir diğer sorun ise azınlık kriterinin "aday ülkeler" için oluşturulması ve "üye devletler” için yerine getirilmesi gereken bir yükümlülük olmadığı gerçeğidir. AB üyesi bazı ülkeler, aday ülkelere kabul ettirilen bazı Sözleşmeleri onaylamamıştır. ${ }^{20}$

\section{AB Koşulluluğu ve Doğu Genişlemesinde Azınlıklar}

Doğu Genişlemesi kapsamındaki ülkelere katı bir şekilde uygulanan koşulluluk ilkesi, AB'nin koşullarına uyması için aday ülke hükümetine dış teşvik sağladığı model üzerine kuruludur. "Dış teşvik modeli” (external incentives model), genel bir tanımla koşullar yerine getirildiğinde aday ülkenin $\mathrm{AB}$ üyesi olacağına işaret eden $\mathrm{AB}$ koşulluluğunun inandırıcıllğ̆ (credibility) ile iç siyasi maliyetlerin

15 Aday ülkelerin Sözleşmelerin içeriğine ilişkin endişelerine karşılık, Grin’e göre örneğin Bölgesel veya Azınlık Dilleri Şartı, Avrupa’nın bölgesel ve azınlık dillerinin varlığını sürdürmeleri için alınabilecek önlemler üzerinedir, Şart'ta etnik grup ya da kolektif haklara atıfta bulunulmamaktadır ve ulusal egemenliğe, toprak bütünlüğüne ve resmi dillerin önemine sayg1 duyulmaktadır. François Grin, Language Policy Evaluation and the European Charter for Regional or Minority Languages, Newyork, Palgrave Macmillan, 2003, s.10 ve 60.

16 Gabriel von Toggenburg, "A Remaining Share or a New Part? The EU's Role vis-a vis Minorities after the Enlargement Decade", Weller et.al., The Protection of Minorities, s.100.

17 Tove H. Malloy, "Forging Cohesion in Diversity: Are National Minorities Promoting Fourth-Level Integration”, Weller et.al., s.55- 69 .

18 Thomas Benedikter (der.), Europe's Ethnic Mosaic, A Short Guide to Minority Rights in Europe, EURAC Research, Esperia, Trento/ Lavis, 2008, s.132-133.

19 Bu konuda bkz. Gwendolyn Sasse, "The Politics of EU conditionality: the norm of minority protection during and beyond EU accession”, Journal of European Public Policy, Cilt 15, No.6, 2008, s.842-860.

20 Belçika, Yunanistan, Lüksemburg FCNM'yi imzalamış ancak onaylamamıştır. Fransa ise ne imzalamış, ne de onaylamıştır Bkz., http://www.coe.int/t/dghl/monitoring/minorities/1_AtGlance/PDF_MapMinorities_bil.pdf. ECRML'yi ise, Fransa, İtalya ve Malta imzalamış ancak onaylamamıştır. Belçika, Yunanistan, İrlanda, Portekiz ve 2004-2007 yılında üye olan Estonya, Letonya, Litvanya, Bulgaristan ne imzalamış, ne de onaylamıştır. http://conventions.coe.int/Treaty/ Commun/ChercheSig.asp?NT=148\&CM=8\&DF=\&CL=ENG (Erişim Tarihi 18 Nisan 2015). 
etkileşimine bağlıdır. Schimmelfennig ve Sedelmeier, AB'nin temel ve demokratik haklara ilişkin koşulları (democratic conditionality) bakımından, $\mathrm{AB}$ inandırıcılığına rağmen, ulusal maliyetlerin $\mathrm{AB}$ etkisini sınırladığını belirtmektedir. Maliyetin büyüklüğü ve veto odakları yanında, koşulların net olup-olmaması, süreç sonunda elde edilecek ödülün büyüklüğü ve elde edilme hızı $\mathrm{AB}$ etkisini belirlemektedir. ${ }^{21}$ Etnik çatışma ve ulusal kimlikle ilgili konular da yüksek siyasi maliyet yaratarak $\mathrm{AB}$ etkisini azaltabilir. ${ }^{22}$

$\mathrm{Bu}$ çerçevede, bu ülkelerin azınlık koşulunu yerine getirip getirmediği konusunda literatürde farklı görüşler vardır. Kimi görüşlere göre, $\mathrm{AB}$ etkisi ile belirli sorunlu ülkelerde azınlıkların durumları iyileşmiş ve çatışma riski azalmıştır. ${ }^{23}$ Kimi görüşlere göre ise, aday ülkeler kriterleri yetersiz ve kısmen uygulamıştır ve bu ülkelerin azınlık koruma sisteminde geniş çaplı bir dönüşüm yaşanmamıştır. ${ }^{24}$ Aslında, azınlık konularında $\mathrm{AB}$ koşulluluğunun etkisini ölçmek zordur, zira $\mathrm{AB}$ 'nin aday ülkede değişiklik yaratması pek çok faktörün bileşimine bağlıdır. Ev sahibi-akraba devlet ve azınlıklar arasındaki ilişkiler, azınlığın siyasi olarak temsil edilip edilmediği, azınlık grupları içinde değişim birimlerinin (change agents) olup olmaması, bu birimlerin hükümet ile ilişkileri, azınlığın organize olup olmaması, toplam nüfusa oranı, coğrafi olarak toplu ya da dağınık olması gibi faktörler $A B$ etkisini tamamlamakta veya engellemektedir. ${ }^{25}$

Ayrıca, AB hukukunda yukarıda belirtilen azınlıklara ilişkin kimi sorunlar, azınlık koşulunun Doğu Genişlemesi ülkelerine uygulamasında sorunlara yol açmıştır. Sorunlara rağmen genel anlamda $\mathrm{AB}$ üyeliğinin azınlıkların konumlarında değişikliklere neden olduğunu ve azınlıklara bazı avantajlar sağladığını söylemek mümkündür. Bu çerçevede azınlıklara mali programlara dâhil olma, serbest dolaşım ve $\mathrm{AB}$ yönetişimine katılma, $\mathrm{AB}$ ile ilişki kurarken kendi dillerini kullanma olanakları sağlanmıştır. Serbest dolaşım özellikle sınır azınlıklarının olduğu bölgelerde önemli hale gelmiştir. ${ }^{26}$ $\mathrm{AB}$ ile bağlantı, azınlıkların birbiriyle bağlantısını da kolaylaştırmışııı. ${ }^{27}$ Bunun yanında azınlıklar, $\mathrm{AB}$ düzeyinde çıkarlarını korumayı ve kanalları etkin bir şekilde kullanmayı öğrenmiştir. ${ }^{28}$ Örneğin Avrupa Parlamentosu seçimleri, azınlı partilerinin görünürlüklerini arttırabilecekleri alternatif bir alan olarak ortaya çıkmıştır. Spirova ve Stefanova, Avrupa Parlamentosu seçimlerine Bulgaristan ve Romanya’daki etnik partilerin katılımı örneğinde azınlıkların temsili konusunu inceledikleri makalede, $\mathrm{AB}$ düzeyindeki siyasi sürecin, bu partiler tarafından azınlıklara ilişkin gündemlerini yerine getirmek için firsat olarak kullanıldığını ortaya koymaktadır. ${ }^{29}$

21 Frank Schimmelfennig ve Ulrich Sedelmeier, "Governance by conditionality: EU rule transfer to the candidate countries of Central and Eastern Europe”, Journal of European Public Policy, Cilt 11, No.4, 2004, s.661-679.

22 Frank, Schimmelfennig, "EU political accession conditionality after the 2004 enlargement: consistency and effectiveness", Journal of European Public Policy, Cilt 15, No.6, 2008, s.918-937.

23 Frank Hoffmeister, "Monitoring Minority Rights in the Enlarged European Union”, Gabriel N. Toggenburg (der.), Minority Protection and the Enlarged European Union: The Way Forward, Local Government and Public Service Reform Initiative Open society Institute,Budapeşte, Macaristan, 2004, s.85; Aimee Kanner Arias ve Mehmet Gurses, “The complexities of minority rights in the European Union”, The International Journal of Human Rights, Cilt 16, No.2, 2012, s.327-330.

24 Sasse, "Minority Rights and EU Enlargement”, s.78; Sadurski, “Minority Protection in Central Europe”, s.209-210; Topidi, EU Law, Minorities and Enlargement, s.212-213.

25 Tamara Hoch-Jovanovic, "Reinventing national Minority Rights through European Integration: from top-down to bottomup Europeanisation", Yayınlanmamış Doktora Tezi, The Department of Society and Globalisation, Roskilde University, Danimarka, 2014, s.19-22, 305-308; Arias ve Gurses, “The Complexities of minority rights”, s.330.

26 Toggenburg, "Minority Protection in a Supranational Context", s.18-19.

27 Jovanovic, "Reinventing national Minority Rights through European Integration, s.7.

28 Toggenburg, "Minority Protection in a Supranational Context", s.20.

29 Maria Spirova ve Boyka Stefanova, “The European Dimension of Minority Political Representation: Bulgaria and 


\section{Macaristan ve Estonya-Letonya Örnekleri}

Azınlık koşulunun uygulandığı ülkelere örnek olarak, farklı gelişmelere konu olan ülkelerden Macaristan ile Estonya ve Letonya incelenecektir. Macaristan örneğinde, $A B$ etkisini incelemek amacıyla komşu ülkelerdeki Macar azınlığa da yer verilmiştir. Bu ülkelerdeki farklı gelişmeler, iç siyasi koşulların azınlık politikaları bakımından önemini göz önünde tutmayı gerektirmektedir. ${ }^{30}$ Doğu Genişlemesi ülkelerinin bir diğer azınlığı Romanların durumu iç politikanın etkisini biraz daha belirginleştirmektedir. Genişleme sürecinde Avrupa çapında genel önlemler alınırken, Romanların durumu özellikle bazı ülkelerde daha olumsuzdur.

Doğu Genişlemesi ülkelerinden Macaristan, AB’nin olumlu etkisinin belirgin olduğu, Estonya ve Letonya ise bu etkinin tartışmalı olduğu ülkelerdir. Avrupa Konseyi çerçeve sözleşmesinin izleme mekanizmasına göre Macaristan, ${ }^{31}$ genişleme sonrası ülkeler arasında söz konusu sözleşmeye en iyi uyum sağlayan ülkedir. 1993 yılında çıarılan yasaya göre, Romanlar da dâhil 13 azınlık grubu resmi azınlık olarak tanınarak, bu azınlıklara yerel düzeyde kendini yönetme hakkı (minority selfgovernments) yanında dil ve eğitim hakları tanınmıştır. Macaristan tam üyeliğin hemen öncesinde kabul ettiği yasa ile Irk Eşitliği Direktifi gereklerini yerine getirmiştir. ${ }^{32}$

Macaristan'ın kendi azınlıklarını güçlendirici ve liberal politikası, komşu ülkelerin de azınlıklar konusunda düzenleme yapması için baskı unsuru olmuştur. Öte yandan Macaristan Parlamentosu tarafından 2001 yılında çıkarılan ve komşu ülkelerde yaşayan Macarlara hak ve yetkiler tanıyan yasa, Macar azınlığın bulunduğu Romanya ve Slovakya'da ${ }^{33}$ tartışmalara sebep olmuştur. Bu doğrultuda Macaristan'ın azınlık koruması, özellikle komşu ülkelerdeki Macar azınlıkları koruma yönündeki ulusal tercih ve çıkarlarını ön plana çıkaran bir örnektir. ${ }^{34} \mathrm{Bu}$ yasa, Avrupa Konseyi Venedik Komisyonu tarafından Ekim 2001 tarihli bir rapor ile değerlendirilmiştir. Rapora göre, akraba devletin düzenlemeleri eğitim ve kültürel alan dışında yapılmamalıdır ve azınlık korumasında sorumluluk esas itibariyle ev sahibi devlettedir. Bu ifade Avrupa azınlık koruma sisteminde önemli bir adımdır zira daha önce resmen ifade edilmemiştir. ${ }^{35} 2001$ yılı ilerleme raporu Venedik Komisyonu sonuçları ile paralel bir çıkarım yapmıştır ve Avrupa Komisyonu tarafsız bir hakem gibi Macaristan’ın gerekli değişiklikleri yapmasını sağlamıştır. ${ }^{36}$

Macar azınlığın yaşadığı ülkelerden Romanya, Macar Azınlık Partisine yönelik düzenlemeleri bakımından dikkate değer bir örnektir. Romanya'da Macar azınlık partisi 1989'da siyasi faaliyetlerine başlamıştır ve Romanya parlamentoda azınlık temsilini sağlamak için düzenlemeler yapmıştır.

Romania Compared”, East European Politics and Societies, Cilt 26, No.1, 2012, s.75-92.

30 İç politikanın belirleyiciliği için bkz. Sasse, "Minority Rights and EU Enlargement”, s.78; Guido Schwellnus et.al.,"It ain't over when it's over: The adoption and sustainability of minority protection rules in new EU member states”, Frank Schimmelfennig ve Florian Trauner (der.), Post-accession compliance in the EU's new member states, European Integration online Papers (EIoP), Özel Sayı 2, Cilt 13, No.24, 2009, http://eiop.or.at/eiop/texte/2009-024a.htm, s.1-28.

31 Macaristan nüfusunun yaklaşık yüzde 5,6'sını azınlıklar oluşturmaktadır. http://www.ksh.hu/nepszamlalas/tables regional_00. (Erişim Tarihi 30 Nisan 2015).

32 Macaristan örneği için bkz. Arias ve Gurses, “The complexities of minority rights in the European Union”, s.326-327.

33 Romanya nüfusunun yüzde 6,5’i, Slovakya nüfusunun yüzde 8,5'i Macar azınlığa mensuptur. http://www.insse.ro/cms/ files/statistici/comunicate/RPL/RPL\%20_rezultate\%20definitive_e.pdf ve http://slovak.statistics.sk (Erişim Tarihi 30 Nisan 2015).

34 Sasse, "Minority Rights and EU Enlargement", s.78.

35 Kinga Gál, “The Hungarian Legislation on Hungarians Living in Neighbouring Countries”, Zoltán Kántor et.al. (der.), The Hungarian Status Law: Nation Building and/or Minority Protection, Slavic Research Center, Hokkaido University, Sapporo, 2004, s.397.

36 Hoffmeister, "Monitoring Minority Rights in the Enlarged European Union”, s.98-100. 
1992 seçim yasası azınlık gruplarının seçim barajına takılmadan parlamentoya girebilmesi için düzenlenmiştir ve azınlıklar fonlarla desteklenmektedir. ${ }^{37}$ Bazı görüşlere göre 1996'dan sonra Romanya'daki Macar azınlık partisinin koalisyon hükümetinde yer almasının en önemli amacı, AvroAtlantik entegrasyonunun bir an önce gerçekleştirilme arzusudur. Zira uluslararası toplum, azınlık sorunlarının kapsamlı bir çözüme kavuşturulmasını talep etmekteydi. ${ }^{38}$

AB'nin hükümet düzeyinde etnik gruplar arasında güç paylaşımını, Macar azınlık partilerinin aktif olarak yer aldığı Romanya ve Slovakya'da olumlu yönde etkilediği görülmektedir. Bu ülkelerde $A B$, azınlığın da temsil edildiği bir seçim platformunun oluşmasını sağlamış, $A B$ yanlısı kamuoyunun da talebi ile bu ülkelerdeki azınlık ve çoğunluk partilerinin Birliğe üyelik amacında birleşmeleri, $A B$ tarafından kabul görecek siyasi pozisyonlar almalarını sağlamıştır. AB, Slovakya'da, Macar azınlık partisinin ortak olduğu koalisyon hükümetinin dağılması tehlikesi karşısında doğrudan müdahil olmuş, Romanya'da ise siyasi güç paylaşımını etkileyen bir çizgi seyretmiştir. ${ }^{39}$

Bunun yanında, $A B$ 'nin azınlık partilerinin taleplerine, ev sahibi devletin tutumuna göre cevap verdiği görülmektedir. $\mathrm{Bu}$ durum Szöcsik'in Macar azınlık partilerinin taleplerinin AB tarafından karşılanma düzeyini Romanya ve Sırbistan örneklerinde incelediği makalesinde ortaya konmaktadır. Her iki ülkedeki Macar partileri benzer taleplerde bulunmasına rağmen AB'nin bu iki ülkeye farklı yaklaşımı dikkate değerdir. Her iki ülkedeki etnik partiler kültürel özerklik talep etmiş, ancak AB sadece Sırbistan'ın talebini desteklemiştir. Zira Romanya'da azınlıklar için kültürel özerklik gündeme geldiyse de hiçbir zaman hükümet programlarında yer almamıştır. Sırbistan'da ise bu konudaki talep daha hızlı karşılanmıştır. AB'nin farklı tutumunda, azınlıklara ilişkin ortak standartların olmaması önemli bir faktördür. $A B$, aday ülkelerin azınlıkları için kültürel özerkliği bir şart olarak ortaya koymamış ancak iç siyasette kabul görmüşse desteklemiştir. ${ }^{40} \mathrm{Bu}$ durum $\mathrm{AB}$ koşullarının uygulanmasında iç siyasetin belirleyiciliğini ortaya koyması bakımından önemlidir. Katılım sürecinde hükümetler, $A B$ ve azınlık talepleri arasında nasıl iki düzeyli bir yaklaşım geliştiriyorlarsa, aslında $A B$ de ilgili ülke ve azınlık talepleri arasinda benzer bir tutum izlemektedir.

Estonya ve Letonya örnekleri, azınlıklar bakımından olumlu $A B$ etkisinin ilk etapta net izlenemediği örnekleri oluşturmaktadır. Bu iki ülkede vatandaş olmayanların çok büyük çoğunluğu bağımsızlık sonrası oluşturulan yasalarla vatandaşlık statüsü alamamış Rus (Rusça konuşan) azınlıklardır. ${ }^{41}$ Baltık ülkeleri arasında en fazla etnik Rus Letonya'da yaşamaktadır. Vatandaş olmayanlara ilişkin düzenlemeler, Letonya'nın $\mathrm{AB}$ üyeliği ve diğer uluslararası kuruluşlar nezdinde karşı karşıya kaldığı temel sorun olmuştur. ${ }^{42}$

37 Sasse, "Minority Rights and EU Enlargement", s.75-76.

38 István Horváth, “Minorities, Minority Protection in Romania”, István Horváth ve Márton Tonk (der.), Minority Politics within the Europe of Regions, The Romanian Institute for Research on National Minorities, Scientia Publishing House, Cluj-Napoca, 2011, s.492-493.

39 Martin Brusis, "Enlargement and Interethnic Power-Sharing Arrangements in Central and Eastern Europe", Weller et.al., The Protection of Minorities, s.232-244.

40 Edina Szöcsik, "The EU Accession Criteria in the Field of Minority Protection and the Demands of Ethnic Minority Parties", Journal on Ethnopolitics and Minority Issues in Europe, Cilt 11, No.2, 2012, s.104-127.

41 Estonya'da nüfusun yüzde 25,1'ini, Letonya'da yüzde 26,9'unu Ruslar oluşturmaktadır. https://www.stat.ee/34278 ve http://www.csb.gov.lv/en/notikumi/key-provisional-results-population-and-housing-census2011-33306.html/ (Erişim Tarihi 30 Nisan 2015).

42 Helen M. Morris, "EU Enlargement and Latvian Citizenship Policy", Journal on Ethnopolitics and Minority Issues in Europe, Cilt 1, 2003, s.2-3. 
Estonya örneğinde, Schulze, $\mathrm{AB}$ koşulluluğunun beklenen başarıyı gösteremediğini ve siyasi elitlerin $\mathrm{AB}$ normlarını içselleştiremediğini belirterek, bu durumun nedeni olarak Rusya'nın Estonya içindeki Rus azınlık ile Estonyalılar arasındaki etnik gerilimi tırmandırıcı aktivizmini göstermektedir. $\mathrm{Bu}$ görüşe göre, İkinci Dünya savaşı sırasında Sovyetler Birliği tarafından yaptırılan Bronz asker anıtının Estonya hükümeti tarafından kaldırılması ve ortaya çıkan ayaklanmalar ve sonrasında Rusya’nın Estonya hükümetine siber saldırıları tehdit algılamasını yükseltmiştir. ${ }^{43}$

Estonya ve Letonya örnekleri $\mathrm{AB}$ etkisinin sorunlu olduğu ülkeler olarak birlikte ele alınsalar da, iki ülke arasında uygulamalar bakımından karşılaşılan farklılıklar, aynı AB koşulu uygulansa dahi iç siyasetin belirleyiciliğinin Estonya ve Letonya örnekleri ile de verilebileceğini göstermektedir. Estonya 1992 Anayasasına Estonya'da daimi olarak ikamet edenlerin yerel seçimlerde oy kullanma hakkı olduğu maddesini koymuştur. Letonya'da ise yerel seçimlerde seçme ve seçilme hakkı sadece Letonya vatandaşlarına, $A B$ üyeliğinden sonra da Letonya'da daimi olarak ikamet eden $A B$ vatandaşlarına tanımış, vatandaş olmayanlar sürece dâhil edilmemiştir. Bu durum ülkede uzun süre siyasi tartışmalara neden olmuştur. Letonya'nın Estonya'dan farklı uygulamaları, Letonyalı elitlerin azınlıkların ülke içindeki dağılımı nedeniyle kendilerini güvende hissetmemelerinden kaynaklanmıştır. Zira Letonya'da Estonya'dan farklı olarak Rus azınlık dağınıktır. Bu durum, vatandaş olmayanlara oy hakkı verildiğinde seçimlerde başkent de dâhil pek çok yerde azınlıkların başarı kazanması anlamına gelebilecekti. Bunun yanında, azınlık partileri Letonya Parlamentosunda etkin konumdayd $1{ }^{44}$

Katılım sürecinde $\mathrm{AB}$ AGİT tavsiyelerini yinelemiş ve Letonya $\mathrm{AB}$ üyeliğini kaybetmemek üzere belirli düzenlemeler gerçekleştirmiştir. Bu kapsamda yeni bir vatandaşlık ve dil yasası (Language Law) oluşturulmuş, eğitim reformu yapılmıştır. Ülke içinde muhalefet nedeniyle uzun bir zaman diliminde gerçekleşen reformlar kapsamında, vatandaşlığa geçişi kolaylaştırıcı düzenlemeler (kota sisteminin kaldırılması, başvuru ücretinin azaltılması, 65 yaşın üstündeki kişilerin dil testinden muaf tutulması, ebeveynleri vatandaşlık statüsü taşımayan çocuklara vatandaşlık verilmesi) yanında, iş piyasasında istihdam edilecek azınlıklara yönelik olarak dil kriterleri bakımından düzenlemeler gerçekleştirilmiştir. Letonya'nın ilerleme sağlamasında, AB'nin Letonya'yı 1997 yılında müzakerelere başlayacak ilk grup ülke arasında saymaması önemli bir etken olmuştur. Ancak düzenlemelerin sürekliliği konusunda endişeler devam etmiştir. ${ }^{45}$ Letonya FCNM'yi ancak 2005 yılında, bazı ek deklarasyonlarla onaylamıştır. Estonya da benzer düzenlemeler ve dil yasası oluşturmuş ancak yasanın ayrımcılığa yol açabilecek bazı düzenlemeleri eleştiri konusu olmuştur. AB etkisi, dil yasaları bakımından her iki ülkede de katılım sonrası uygulama aşamasında sınırlı kalmıştır. ${ }^{46}$

Agarin’e göre, Baltık ülkeleri bugün Batı kurumlarının eşit üyesi olsalar ve AB bu ülkeler üzerinde baskı oluştursa da, çoğunluk kurumları devlet ve toplum arasındaki ilişkilere hâkim konumdadır. 1990’lar boyunca bu ülkelerde azınlıklar devlet ve ulus inşa sürecinden dışlanmıştır ve bu durumun etkileri sürmektedir. ${ }^{47}$

43 Jennie L. Schulze, “Estonia caught between East and West: EU conditionality, Russia's activism and minority integration”, Nationalities Papers: The Journal of Nationalism and Ethnicity, Cilt 38, No.3, 2010, s.368-376.

44 Licia Cianetti, "Granting Local Voting Rights to Non-Citizens in Estonia and Latvia: The Conundrum of Minority Representation in Two Divided Democracies”, Journal on Ethnopolitics and Minority Issues in Europe, Cilt 13, No.1, 2014, s.86-87 ve $96-99$.

45 Morris, "EU Enlargement and Latvian Citizenship Policy", s.1-33.

46 Sasse, "The Politics of EU conditionality", s.850-853.

47 Timofey Agarin, A Cat's Lick: Democratisation and Minority Communities in the Post-Soviet Baltics, Rodopi, Amsterdam, 2010, s.127-128 ve 317-321. 


\section{Türkiye Örneği}

Türkiye'nin $\mathrm{AB}$ sürecinde azınlık konuları ile ilgili temel politikası, Kopenhag kriterlerini yerine getirmeye çalışırken, gayri-Müslimleri (uygulamada sadece Ermeniler, Rumlar ve Museviler) azınlık kabul eden Lozan Antlaşması hükümleri içinde kalmak ve geleneksel azınlık rejiminde herhangi bir değişikliğe izin vermemektir. Bu çerçevede Türkiye, ilgili AB mevzuatını seçici bir şekilde uyumlaştırma yoluna gitmektedir. ${ }^{48}$

1998-2014yıllarıarasında Türkiye için hazırlanan ilerleme raporlarında insan haklarıve azınlıklar başlığının ardından, Güney ve Güney Doğu'daki durum başlığı altında Kürt meselesindeki gelişmeler değerlendirilmektedir. ${ }^{49}$ Raporların geneli incelendiğinde, İnsan Hakları ve Azınlıklar başlığı altında, Türkiye'nin yıllar içinde kültürel haklar konusunda ilerleme kaydettiği vurgulanmaktadır. Ayrıca, bazı eksikliklere rağmen, Kürtçe’nin günlük yaşamda kullanımına yönelik kısıtların kalktığı, Kürtçe radyo ve TV yayınına izin verildiği, Kürtçe öğrenim konusunda ilerleme kaydedildiği vurgulanmaktadır. Yıllar içinde özel okul ve kurslara izin verildiği, Kürtçe yayın kapsamında genişleme olduğu ve mahkemelerde ve siyasi faaliyetlerde Kürtçe'nin yaygınlaşması konuları belirtilmektedir. ${ }^{50}$ Ancak tüm ilerleme raporlarında Türkiye'nin azınlıklarla ilgili mevcut kısıtlayıcı yasal çerçevesinin değişmediği, Lozan Antlaşması'nda belirtilenler dışında azınlık kabul edilmediği ancak bu durumun, söz konusu tanım dışında kalanlara etnik köken, dil ve din temelinde haklar verilmesine engel olmaması gerektiği belirtilmektedir. Ayrıca Türkiye’nin ilgili BM Sözleşmelerine koyduğu çekinceler ve azınlıklara ilişkin temel Avrupa Konseyi Sözleşmelerini imzalamaması olumsuz noktalar olarak belirtilmektedir.

Bu noktada, Türkiye'nin Kürtleri azınlık olarak görmediği ve Kürtlerin de kendilerini azınlık olarak kabul etmediği belirtilmelidir. Türkiye tarafından ülke bütünlüğune yönelik endişeler ile de açıklanabilecek bu tutum, ortak bir azınlık düzenlemesi yapabilmek açısından Kürt meselesini AB için zorlayıcı bir örnek konumuna getirirken, oluşturulan politikalarda iç siyasi koşulların belirleyiciliğini ortaya koyması bakımından da dikkate değerdir. ${ }^{51}$

Türkiye'nin Kürt meselesi konusunda demokratik reformlar gerçekleştirmesinde AB'nin Türkiye’yi 1999 yılında aday ülke ilan etmesi tetikleyici rol oynamıştır. Katılım müzakerelerinin açılması kararının alınmasında da, Türkiye’nin Kürt meselesi ve diğer konularda gerçekleştirdiği reformlar etkili olmuş, $\mathrm{AB}$ etkisi meseleye bakışta iç siyasi dengeleri değiştirmiştir. ${ }^{52}$ Bazı yorumlara göre, $A B$ ’ye aday ülke kabul edilmesi ve müzakerelerin Kıbrıs sorunu nedeniyle duraklaması arasında geçen sürede Türkiye'nin Kürtçe eğitim ve kültürel haklar konusunda gerçekleştirdiği reformlarda, yüksek siyasi maliyet ve güçlü veto odaklarına rağmen AB'nin Türkiye'ye karşı inandırıcı bir taahhüt altına girmesi etkili olmuştur. Kıbrıs sorunu nedeniyle bazı müzakere fasıllarının dondurulması ve $A B$ üyesi ülkelerin Türkiye'nin üyeliği karşıtı açılamaları bir süre sonra inandırıcı $A B$ taahhüdünü ortadan kaldırmıştır. ${ }^{53}$ Benzer bir yoruma göre, yerel seçimlerde kaybedilen Kürt oylarına yönelik olarak 2009 yılında ortaya konan Kürt açılımı, AB etkisinin zayıflaması ve bu durumun iç politikaya

48 Sule Toktaş ve Bulent Aras, “The EU and Minority Rights in Turkey”, Political Science Quarterly, Cilt 124, No.4, 20092010, s.697-711.

49 Türkiye ilerleme raporları için bkz.http://ec.europa.eu/enlargement/countries/detailed-country-information/turkey/ index_en.htm.

50 Reformların analiz ve incelemesi için bkz. Kemal Kirişçi, “The Kurdish Issue in Turkey: Limits of European Union Reform”, South European Society and Politics, Cilt 16, No.2, 2011, s.335-340.

51 Bu noktaya dikkatimi çeken Uluslararası İlişkiler dergisi hakemine teşekkür ederim.

52 Kirişçi, “The Kurdish Issue in Turkey”, s.337-339.

53 Frrat Cengiz ve Lars Hoffmann, "Rethinking Conditionality: Turkey's European Union Accession and the Kurdish Question”, JCMS, Cilt 51, No.3, 2013, s.416-424. 
olumsuz yansımaları nedeniyle sonuca ulaşamamıştır. Ancak yine de, belirli dönemlerde, AB etkisi meselenin ele alınmasında farklı görüşlerin ifade edilmesini sağlaması bakımından Türkiye'de bir dönüşüme yol açmıştır. ${ }^{54}$

Ancak, AB’nin Türkiye'nin üyeliği konusunda 2004 yılından itibaren düşmeye başlayan inandırıcılığına rağmen, Türkiye'de gerçekleştirilen demokratik reformların sebebini 2002-2009 yılları arasında hükümetin seçmen nezdinde ve iç siyasette $A B$ şartlarına uyumdan fayda sağlamasına bağlayan yorumlar vardır. ${ }^{55}$ Bir başka görüşe göre ise, katılım sürecinde azınlık konularında $A B^{\prime} y e$ uyumda Türkiye'de görülen değişimler, $A B$ ve Türkiye'nin karşılıklı oluşturdukları itme-çekme dengesi ile gerçekleşmiştir. ${ }^{56} \mathrm{Bu}$ saptamalar da iç siyasi etkenlerin öneminin yadsınmaması gerektiğini ortaya koymaktadır.

Kurban’a göre, Kürt meselesinde $\mathrm{AB}$ katılım süreci ile başlayan demokratikleşme ve reform sürecini tetikleyen Türkiye'nin AB'ye girebileceği fikri olsa da, süreçiçinde Türkiye'nin Kürt meselesine bakışı değişmemiştir. Kürtlere verilecek haklar Türkiye tarafından $A B$ üyeliği için küçük tavizler olarak görülürken, Kürt tarafı bir süre daha fazla hak talebi ile AB'yi hükümete baskı yapmaya çağırmıştır. Zira $\mathrm{AB}$ süreci kapsamında gerçekleştirilen reformlar yeterli görülmemiştir. Ancak, Avrupa'nın kendi terör sorunları, 11 Eylül sonrası ortam, terörist örgüt kabul edilen PKK'ya olumsuz tutum ve AİHM'nin işleyişine ilişkin bazı değişiklikler 2000'li yıllarda Kürt hareketinin Avrupalı kuruluşları harekete geçirmesini zorlaştırmıştır. ${ }^{57}$ Aslında daha önce, 1990 'lı yıllardan itibaren özellikle Almanya'da yaşayan Türk ve Kürtler arasındaki şiddetin artması ve PKK’nın Avrupa'nın güvenliğine tehdidi nedeniyle Kürt hareketine destek azalmıştır. Avrupa'ya yansıyan şiddet yanında, Türkiye soruna siyasi bir çözüm bulması gerektiği yönünde eleştirilmiştir. Ancak bu eleştiriler Batı’nın ülkeyi bölmek istediği şeklinde yorumlanmıştır. ${ }^{58}$ Kürt meselesinin çatışma unsurları taşıyan yönüyle Avrupa güvenliğini doğrudan etkilemesi ve bu nedenle $A B$ 'nin mesafeli yaklaşmasına rağmen, $A B$ yine de, diğer aday ülkeler gibi Türkiye'ye de, azınlık koşulu bağlamında hak temelli yaklaşımın gereklerinin yerine getirilmesi ve meselenin çözümü için tedbirlerin alınması gereğini yinelemiştir. Gerçekleştirilen reformların etkisi yadsınamamakla birlikte, gerek $\mathrm{AB}$, gerekse Türkiye'den kaynaklanan sebepler nedeniyle (azalan inandırıcılık ve $A B$ politikalarından kaynaklanan sorunlar, Türkiye- $A B$ ilişkilerinin olumsuz gidişatı gibi) $\mathrm{AB}$ etkisi azalmıştır.

Meseleye $A B$ ve Türkiye'nin farklı dış politika vizyonları ile yaklaştığı, Avrupa'nın kimlik eksenli politikalar ile baktı̆̆ı, Türkiye'nin ise terör sorunu olarak gören güvenlik yaklaşımı sergilediği yönündeki görüş ${ }^{59}$ yanında, ilk bölümde açıklanan "güvenlik-haklar bağı" çerçevesinde, AB

54 Kirişçi, “The Kurdish Issue in Turkey”, s.344-345.

55 Beken Saatçioğlu, "Revisiting the Role of Credible EU Membership Conditionality for EU Compliance: The Turkish Case”, Uluslararası İlişkiler, Cilt 8, No.31 (Güz 2011), s.23-25.

56 Gözde Yılmaz, "It is Pull-and-Push that Matters for External Europeanization! Explaining Minority Policy Change in Turkey”, Mediterranean Politics, Cilt 19, No.2, 2014, s.239.

57 Dilek Kurban, “To Europe and Back: The Three Decades of Kurdish Struggle in Turkey”, Global Turkey in Europe Series, Policy Brief [7], Essen/Istanbul/Rome, 2013, http://ipc.sabanciuniv.edu/en/publication/to-europe-and-backthe-three-decades-of-kurdish-struggle-in-turkey/, (Erişim Tarihi 15 Ağustos 2014), s.2-3. AB etkisini sınırlayan bu faktörlere ek olarak, AB’nin 2005-2009 yılları arasında etkin olan DTP örneğinde Kürt milliyetçiliğine etkisini araştıran Saylan’a göre, Türkiye'nin AB üyesi olmaması nedeniyle resmi kanalların kullanılamaması ve Türkiye'nin merkeziyetçi idari yapısı da, AB etkisini sınırlamıştır. İbrahim Saylan, "The Europeanization process and Kurdish nationalism in Turkey: the case of the Democratic Society Party", Nationalities Papers: The Journal of Nationalism and Ethnicity, Cilt 40, No.2, 2012, s.185-202.

58 Kemal Kirişçi ve Gareth M. Winrow, The Kurdish Question and Turkey, An Example of a Trans-state Ethnic Conflict, Frank Cass \& Co.Ltd, 1997, s.172-173.

59 Erol Kurubaş, "Etnik Sorun-Dış Politika İlişkisi Bağlamında Kürt Sorununun Türk Dış Politikasına Etkileri”, Ankara 
yaklaşımındaki güvenlik endişeleri göz ardı edilmemelidir. Kürt meselesi, gerek Türkiye’de yaşanan terör olayları, gerekse bu durumun Avrupa'ya yansımaları nedeniyle mevcut durumuyla $A B$ için güvenlik endişesi yaratmaya devam etmektedir.

\section{Sonuç ve Değerlendirme}

Azınlık koşulu ile $A B$, aday ülkelerin azınlık korumasında belirli düzenlemelere neden olmuştur. $A B$ azınlık mevzuat ve politikalarındaki dağınıklık ve eksiklikler net standartların oluşmasına engel olsa da $A B$, bu ülkelerdeki kimi sorunlarda tarafsız bir hakem gibi hareket ederek siyasi güç dengelerini etkilemiştir. $\mathrm{AB}$ azınlık politikalarının gerek ülke içinde, gerekse komşu ülkelerdeki Macar azınlıkları koruma yönündeki tercihlerine uyması nedeniyle, Macaristan'ın azınlık koşuluna uyumunu kolaylaştırmıştır. Komşu ülkelerdeki Macar azınlıklar bakımından AB, Macaristan'ın etkisinin kabul edilir düzeyde kalmasını sağlamıştır. Macaristan’a kıyasla azınlık nüfusu hayli fazla Estonya ve Letonya örneklerinde ise, azınlıklara akraba güçlü bir devletin olması ve toplumsal ve siyasi tehdit algılamaları $A B$ etkisini zayıflatmıştır. Buna rağmen $A B$ üyesi olabilme isteğinin etkisi ile vatandaşlık temelinde azınlık politikalarına ağırlık verilerek $\mathrm{AB}$ tarafından kabul görecek seviyeye gelinmesi sağlanmıştır. Ancak uygulamada sorunlar uzun süre devam etmiş, bu durumun etkileri günümüze yansımıştır.

Makalede incelenen örneklerle karşılaştırıldığında, azınlıklara ilişkin standartlar ve yaptırım mekanizmalarının eksikliği ve sorunların siyasi olarak tartışmalı olması nedeniyle, Estonya ve Letonya örneklerine benzer şekilde Türkiye'de de reformların gerektiği gibi uygulanmaması ve sürekliliğinin sağlanamaması önemli bir sorun teşkil edebilir. ${ }^{60}$

Macaristan örneğinde, $A B$ azınlık politikalarının iç siyasi tercih bu yönde ise daha sorunsuz uygulanması, Türkiye örneğinde ancak belirli dönemlerde gerçekleşebilmiştir. AB etkisinin ülkeler tarafından nasıl karşılandığı noktasında ise, Türkiye'nin ülke bütünlüğüne yönelik endişelerinde Estonya ve Letonya'ya benzer durumda olduğu söylenebilir. Estonya örneğinde güçlü bir akraba devlet tarafından, Letonya örneğinde ise buna ek olarak, azınlığın ülke içinde dağılım ve aktivizminden kaynaklanan tehdit algısı, Türkiye örneğinde de, $A B$ reformlarının ülke bütünlügünü tehlikeye atabileceği yönünde ortaya çıkmıştır.

$\mathrm{AB}$ diğer aday ülkelere yönelik taleplerini Türkiye için de yinelemekte ancak, azınlık politikasına hâkim farklı yaklaşımlar ve her ülkenin sorunlarının kendine özgü nitelikleri nedeniyle, konuya yaklaşımda net bir çözüm önerememektedir. Ancak, Türkiye'de bu konuda gerçekleştirilen reformlara rağmen, Doğu genişlemesi ülkeleri ilerleme raporlarında da üzerinde durulan konularda, Türkiye’nin daha fazla reform yapması gerekeceği yönündeki olası AB söylemi, siyasi tartışmaları beraberinde getirebilir. Ayrıca güvenlik endişeleri, AB'nin Türkiye'ye meseleyi çözüme kavuşturacak önlemleri alması için daha fazla "baskı" yapmasına neden olabilir. Bunun yanında, makalede incelenen Doğu genişlemesi ülkelerinin tecrübelerine benzer şekilde, $A B$ süreci Türkiye'de adem-i merkeziyetçi yapının güçlendirilmesine yönelik gelişmeleri ve bu gelişmelerin meseleye ilişkin sonuçlarını gündeme getirebilir. Ayrıca, AB’nin sağladığı olanaklar ile Türkiye Kürtleri ile Avrupa'daki Kürt gruplar arasında etkileşim artabilir ve Kürt siyasi partileri gerek Türkiye, gerekse Avrupa düzeyinde

Avrupa Çalışmaları Dergisi, Cilt 8, No.1, 2009, s.58-59.

60 Türkiye’nin uygulama sorunlarının nedenini $\mathrm{AB}$ azınlı politikalarının tutarlı ve açı olmayışına bağlayan benzer bir görüş için bkz. Hakan Taşdemir ve Murat Saraçlı, "Avrupa Birliği ve Türkiye Perspektifinden Azınlık Hakları Sorunu”, Uluslararası Hukuk ve Politika, Cilt 2, No.8, 2007, s.35. 
daha fazla görünürlük kazanabilir. Ancak $A B$ etkisinin ortaya çıkması, Türkiye- $A B$ ilişkilerinin seyrine ve - dış teşvik modeli bağlamında da açılkanabilecek- iç siyasi maliyet ve tercihler ile inandırıcı $A B$ taahhüdü arasındaki etkileşime bağlı kalacaktır.

Doğu genişlemesi ülkelerinin incelenen örneklerinde, iç siyasi koşullar belirleyici olsa da, inandırıcı $A B$ taahhüdünün olması, iç siyasi tercihlerin $A B$ ile uyumlu şekilde oluşturulmasını kolaylaştırmıştır. Ancak incelenen ülkelerden farklı olarak, Türkiye için inandırıcı $A B$ taahhüdünün ve Türkiye'nin $A B$ üyesi olacağına dair umudunun azalması, meseleye bakışta $A B$ etkisini azaltan ve iç siyasetin belirleyiciliğini arttıran faktörlerdir.

Öte yandan, Kürt meselesine yönelik politikaların olası siyasi ve toplumsal maliyetleri düşünüldüğünde, $A B$ ’nin demokratik koşulluluğu bağlamında, ulusal maliyetlerin $A B$ etkisini sınırladığı yönündeki "dış teşvik modeli" önermeleri ile açıklanabilecek başka bir yön de bulunmaktadır. ${ }^{61}$ Yine bu model ile paralel olarak, $\mathrm{AB}$ politikasının sorunları da, $\mathrm{AB}$ etkisini azaltmaktadır. $\mathrm{AB}$ hukukunda azınlıklara ilişkin temel mevzuat olmaması, diğer ilgili mevzuatın dağınık olması, aday ülkeler için ölçüt ve yaptırım mekanizmalarının olmaması ve iç politikaya geniş uygulama alanı veren yaklaşım, Türkiye'nin Kürt meselesinin ele alınmasında geleneksel tutumunu sürdürmesini kolaylaştırmaktadır.

Ayrıca, makalede incelendiği üzere, hak temelli bir politika sürdürülmesine rağmen, azınlık politikasında standartların net olmaması gibi faktörlerin de etkisiyle, siyasi partilerin etnik konularla ilgili talepleri iç politikada kabul görüyorsa $\mathrm{AB}$ tarafından desteklenmektedir. $\mathrm{Bu}$ nedenle Kürt meselesinin iç politikada nasıl ele alınacağı konusu önem kazanmaktadır.

İncelenen örneklere benzer şekilde, $A B$ Kürt meselesinde de Türkiye'nin siyasi dengelerini zaman zaman etkilemiştir. Ancak Türkiye'de reformların başlamasında itici güç olsa da, AB etkisi reformların sürdürülmesi ve uygulanması bakımından zaman içinde sınılı kalmıştır. Çatışma unsurları barındıran mevcut haliyle Kürt meselesi, $\mathrm{AB}$ için Doğu genişlemesinde ön plana çıkan bazı azınlık sorunlarından daha fazla güvenlik endişesi yaratmaktadır.

61 Bkz. Frank Schimmelfennig, Stefan Engert, Heiko Knobel, "Costs, Commitment and Compliance: The Impact of EU Democratic Conditionality on Latvia, Slovakia and Turkey”, JCMS, Cilt: 41, No.3, 2003,s.506-509. Maliyet ve inandırıc1 $\mathrm{AB}$ taahhüdü bağlamında dış teşvik modeline ilişkin eleştirel bir görüş için bkz. Cengiz ve Hoffmann, "Rethinking Conditionality: Turkey's European Union Accession and the Kurdish Question”, s. 425-429. 


\section{Kaynakça}

Agarin, Timofey. A Cat's Lick: Democratisation and Minority Communities in the Post-Soviet Baltics, Rodopi, Amsterdam, 2010.

Benedikter, Thomas (ed.). Europe's Ethnic Mosaic, A Short Guide to Minority Rights in Europe, Esperia, Trento/ Lavis, EURAC Research, 2008.

Brusis, Martin. "Enlargement and Interethnic Power-Sharing Arrangements in Central and Eastern Europe", Marc Weller et.al. (der.). The Protection of Minorities in the Wider Europe, Palgrave Macmillan, 2008, s.232-250.

Cengiz, Firat ve Lars Hoffmann. "Rethinking Conditionality: Turkey's European Union Accession and the Kurdish Question”, JCMS, Cilt 51, No.3, 2013, s.416-432.

Cianetti, Licia. "Granting Local Voting Rights to Non-Citizens in Estonia and Latvia: The Conundrum of Minority Representation in Two Divided Democracies", Journal on Ethnopolitics and Minority Issues in Europe, Cilt 13, No.1, 2014, s.86-112.

Gál, Kinga. "The Hungarian Legislation on Hungarians Living in Neighbouring Countries", Zoltán Kántor et.al. (der.). The Hungarian Status Law: Nation Building and/or Minority Protection, Sapporo, Slavic Research Center, Hokkaido University, 2004, s.396-410.

Galbreath, David ve Joanne Mcevoy. "European organizations and minority rights in Europe: On transforming the securitization dynamic", Security Dialogue, Cilt 43, No.3, 2012, s.267-284.

Galbreath, David ve Joanne Mcevoy. The European Minority Rights Regime, Towards a Theory of Regime Effectiveness", ABD, Palgrave Macmillan, 2012.

Grin, François. Language Policy Evaluation and the European Charter for Regional or Minority Languages, Newyork, Palgrave Macmillan, 2003.

Hoffmeister, Frank. "Monitoring Minority Rights in the Enlarged European Union", Gabriel N. Toggenburg (der.), Minority Protection and the Enlarged European Union: The Way Forward, Budapeşte, Macaristan, Local Government and Public Service Reform Initiative Open society Institute, 2004, s.85-106.

Horváth, István. "Minorities, Minority Protection in Romania", István Horváth ve Márton Tonk (der.), Minority Politics within the Europe of Regions, Cluj-Napoca, The Romanian Institute for Research on National Minorities, Scientia Publishing House, 2011, s.475-500.

Hughes, James ve Gwendolyn Sasse. "Monitoring the Monitors: EU Enlargement Conditionality and Minority Protection in the CEECs", Journal on Ethnopolitics and Minority Issues in Europe, Cilt 1, 2003, s.1-37.

Jovanovic, Tamara Hoch. "Reinventing national Minority Rights through European Integration: from top-down to bottom-up Europeanisation" Yayınlanmamış Doktora Tezi, Danimarka, The Department of Society and Globalisation Roskilde University, 2014.

Kanner Arias, Aimee ve Mehmet Gurses. "The complexities of minority rights in the European Union", The International Journal of Human Rights, Cilt 16, No.2, 2012, s.321-336.

Kirişçi, Kemal. “The Kurdish Issue in Turkey: Limits of European Union Reform”, South European Society and Politics, Cilt 16, No.2, 2011, s.335-349.

Kirişçi, Kemal ve Gareth M. Winrow. The Kurdish Question and Turkey, An Example of a Trans-state Ethnic Conflict, Büyük Britanya, Frank Cass \& Co.Ltd, 1997.

Kurban, Dilek. “To Europe and Back: The Three Decades of Kurdish Struggle in Turkey”, Global Turkey in Europe Series, Policy Brief [7], Essen/Istanbul/Rome, 2013, s.1-5, http://ipc.sabanciuniv.edu/en/publication/toeurope-and-back-the-three-decades-of-kurdish-struggle-in-turkey, (Erişim Tarihi 15 Ağustos 2014).

Kurubaş, Erol. "Etnik Sorun-Dış Politika İlişkisi Bağlamında Kürt Sorununun Türk Dış Politikasına Etkileri”, Ankara Avrupa Çalışmaları Dergisi, Cilt 8, No.1, 2009, s.39-69.

Kymlicka, Will. “The Evolving Basis of European Norms of Minority Rights: Rights to Culture, Participation and Autonomy", Marc Weller et.al. (der.), The Protection of Minorities in the Wider Europe, Palgrave Macmillan, 2008, s.11-41. 
Malloy, Tove H. "Forging Cohesion in Diversity: Are National Minorities Promoting Fourth -Level Integration”, Marc Weller et.al. (der.), The Protection of Minorities in the Wider Europe, Palgrave Macmillan, 2008, s.54-91.

Morris, Helen M. "EU Enlargement and Latvian Citizenship Policy”, Journal on Ethnopolitics and Minority Issues in Europe, Cilt 1, 2003, s.1-38.

Pan, Christoph ve Beate Sibylle Pfeil. National Minorities in Europe: Handbook, Viyana, Braumüller, 2003.

Saatçioğlu, Beken. "Revisiting the Role of Credible EU Membership Conditionality for EU Compliance: The Turkish Case”, Uluslararası İlişkiler, Cilt 8, No.31 (Güz 2011), s.23-44.

Sadurski, Wojciech. "Minority Protection in Central Europe and Accession to the EU”, Marc Weller et.al. (der.), The Protection of Minorities in the Wider Europe, Palgrave Macmillan, 2008, s. 209-231.

Sasse, Gwendolyn. "Minority Rights and EU Enlargement: Normative Overstretch or effective conditionality?" Gabriel N. Toggenburg (der.), Minority Protection and the Enlarged European Union: The Way Forward, Budapeşte, Macaristan, Local Government and Public Service Reform Initiative Open Society Institute, 2004, s.59-83.

Sasse, Gwendolyn. "Securitization or Securing Rights? Exploring Conceptual Foundations of Policies towards Minorities and Migrants in Europe”, JCMS, Cilt 43, No.4, 2005, s.673-693.

Sasse, Gwendolyn. "The Politics of EU conditionality: the norm of minority protection during and beyond EU accession”, Journal of European Public Policy, Cilt 15, No.6, 2008, s.842-860.

Saylan, İbrahim. "The Europeanization process and Kurdish nationalism in Turkey: the case of the Democratic Society Party”, Nationalities Papers: The Journal of Nationalism and Ethnicity, Cilt 40, No.2, 2012, s.185-202.

Schimmelfennig, Frank Stefan Engert, Heiko Knobel, “Costs, Commitment and Compliance: The Impact of EU Democratic Conditionality on Latvia, Slovakia and Turkey”, JCMS, Cilt: 41, No.3, 2003,s.495-518.

Schimmelfennig, Frank ve Ulrich Sedelmeier. "Governance by conditionality: EU rule transfer to the candidate countries of Central and Eastern Europe”, Journal of European Public Policy, Cilt 11, No.4, 2004, s.661-679.

Schimmelfennig, Frank. "EU political accession conditionality after the 2004 enlargement: consistency and effectiveness”, Journal of European Public Policy, Cilt 15, No.6, 2008, s.918-937.

Schulze, Jennie L. "Estonia caught between East and West: EU conditionality, Russia's activism and minority integration”, Nationalities Papers: The Journal of Nationalism and Ethnicity, Cilt 38, No.3, 2010, s.361-392.

Schwellnus, Guido et.al."It ain't over when it's over: The adoption and sustainability of minority protection rules in new EU member states”, Frank Schimmelfennig and Florian Trauner (der.), Post-accession compliance in the EU's new member states, European Integration online Papers (EIoP), Özel Sayı 2, Cilt 13, No.24, 2009, http://eiop.or.at/eiop/texte/2009-024a.htm, s.1-28.

Spirova, Maria ve Boyka Stefanova. “The European Dimension of Minority Political Representation: Bulgaria and Romania Compared”, East European Politics and Societies, Cilt 26, No.1, 2012, s.75-92.

Szöcsik, Edina. “The EU Accession Criteria in the Field of Minority Protection and the Demands of Ethnic Minority Parties", Journal on Ethnopolitics and Minority Issues in Europe, Cilt 11, No.2, 2012, s.104-127.

Taşdemir, Hakan ve Murat Saraçlı. "Avrupa Birliği ve Türkiye Perspektifinden Azınlık Hakları Sorunu”, Uluslararası Hukuk ve Politika, Cilt 2, No.8, 2007, s.25-35.

Toggenburg, Gabriel. "Minority Protection in a Supranational Context: Limits and Opportunities”, Gabriel N. Toggenburg (der.), Minority Protection and the Enlarged European Union: The Way Forward, Budapeşte, Macaristan, Local Government and Public Service Reform Initiative Open society Institute, 2004, s.1-36.

Toggenburg, Gabriel. "A Remaining Share or a New Part? The EU's Role vis-a vis Minorities after the Enlargement Decade", Marc Weller et.al. (der.), The Protection of Minorities in the Wider Europe, Palgrave Macmillan, 2008, s.95-127.

Toktaş, Sule ve Bulent Aras. “The EU and Minority Rights in Turkey”, Political Science Quarterly, Cilt 124, No.4, 2009-2010, s.697-720.

Topidi Kyriaki. EU Law, Minorities and Enlargement, Antwerp-Oxford-Portland, Intersentia, 2010. 
Anneleen Van Bossuyt. "Fit for Purpose or Faulty Design? Analysis of the Jurisprudence of the European Court of Human Rights and the European Court of Justice on the Legal Protection of Minorities”, JEMIE, Sayı 1, 2007, s.1-20.

Yılmaz, Gözde. "It is Pull-and-Push that Matters for External Europeanization! Explaining Minority Policy Change in Turkey", Mediterranean Politics, Cilt 19, No.2, 2014, s.238-258.

\section{Diğer kaynaklar:}

http://www.coe.int

http://ec.europa.eu/enlargement/

http://www.insse.ro

http://slovak.statistics.sk

http://www.ksh.hu

https://www.stat.ee

http://www.csb.gov.lv/ 